\title{
The Harmonization of Braden Scale Assessments with Planned Interventions in Pressure Ulcer Prevention
}

1 Režić Slađana

2 Pauker Kristina

2 Barišić Ivana

1 UHC Zagreb, Department of Health Care Quality Assurance and Development, Kišpatićeva 12, 10000 Zagreb, Croatia

2 UHC Zagreb, Clinic for Pulmonary Diseases Jordanovac, Department of Respiratory Insufficiency and Diseases of Pulmonary Circulation, Intensive Care Unit, Jordanovac 104, 10000 Zagreb, Croatia

Article received: 17.09.2017.

Article accepted: 22.11.2017.

Author for correspondence:

Slađana Režić, e-mail: sladjana.rezic@gmail.com

DOI: $10.24141 / 2 / 1 / 1 / 6$

Keywords: Braden scale, pressure ulcer prevention, nursing care plan, the algorithm of interventions for the treatment of pressure ulcers

\section{Abstract}

Introduction: The Braden scale is a tried and tested pressure ulcer risk assessment scale. It is part of nursing documentation in the Republic of Croatia and is used in all hospitals as a tool for pressure ulcer risk assessment. By using the Braden scale, nurses can determine which interventions should be performed to prevent pressure ulcers.

Aim: A prospective study was conducted in the Respiratory Intensive Care Unit during one month, with the goal of determining the harmonization level between the Braden scale assessment and the planned interventions for the nursing diagnosis of "high risk of pressure ulcers". The aim was also to determine if the Braden scale assessment is used for all admitted patients, if the Braden scale assessment is used daily for all patients and if nursing care plans are made for patients who have a risk of pressure ulcer development.

Methods: A form was created for the purpose of conducting this study. The form contains patient data on sex, admission and discharge dates, as well as data regarding the Braden scale assessment at the moment of admission, during the stay in the ICU and at discharge.

Results: The study included 23 patients. 20 patients had pressure ulcer risk as assessed by the Braden scale. For 8 patients, a nursing care plan for "high risk of pressure ulcers" was written and interventions were conducted that showed very good harmonization with the parameters of the Braden scale. 
Conclusion: Although the Braden scale is a pressure ulcer risk assessment tool, the study shows broader application possibilities. This refers to the possibility of using the parameters of the Braden scale as guidance for choosing interventions.

\section{Introduction}

The Braden scale is a tried and tested pressure ulcer risk assessment tool (1). It is an integral part of the nursing documentation in the Republic of Croatia and is used in all hospitals as a tool for the assessment of pressure ulcer risk. It consists of 6 parameters: sensory perception, moisture, activity, mobility, nutrition, friction and shear. The scores range from 6 to 23, the lower scores showing a higher risk of pressure ulcers (1). By using the Braden scale, nurses can determine which interventions should be performed to prevent pressure ulcers. It is of special importance to pay attention to the Braden scale parameters because they enable us to determine specific interventions for a specific patient (2).

Available algorithms show that interventions for pressure ulcer prevention can be divided according to the cumulative point score and according to the subscale scores of the parameters that make up the Braden scale (3). The use of such algorithms is not common in Croatia, although it would, in our opinion, enable nurses to define interventions for patients with a high risk of pressure ulcers more easily.

Gadd and Morris feel that the use of the Braden scale in such a way that interventions are planned according to the score from the Braden scale parameters can be an effective way of preventing pressure ulcers in hospitals $(4,5)$.

\section{Methods}

The prospective study included patients from the Respiratory Intensive Care Unit during the period between February $27^{\text {th }}$ and March $27^{\text {th }} 2017$. The study was conducted at the Clinic for Pulmonary Diseases Jordanovac, Zagreb. During this month-long study, there were 23 patients in the Respiratory Intensive Care Unit - 15 were male and 8 female. The average age of the patients was 54.8 (36-84 years of age). The average bed days amounted to 9.86 days (ranging from 1 to 21 days). For every patient, a Braden scale assessment was made at admission as well as daily during their stay on the ward as part of the nursing documentation. The Braden scale assessment was done by nurses in charge of the patient, whereas the nursing care plan was done by the shift manager or the ward's head nurse. For this purpose, a form was created which contained the admission and discharge dates, as well as data regarding the Braden scale assessment at the moment of admission, during the stay in the Respiratory Intensive Care Unit (RICU) and at discharge. Using the form, the point score was monitored for every patient according to every parameter of the Braden scale in order to determine the margin point score and the need for interventions that would arise from that.

\section{Results}

Of the 23 patients hospitalized in the RICU during the month-long study, 20 had a risk of sustaining pressure ulcers at admission and during their stay in the RICU. None of the patients admitted in the RICU during the study have previously had pressure ulcers. Table 1 shows the point score for the 23 patients hospitalized in the RICU. The table shows the number of patients admitted during that time, distributed according to the parameters of the Braden scale, with the assessment done at patient admission. It also shows the average number of bed days for the aforementioned number of patients, as well as any changes in the point score of the Braden scale during their stay on the ward. The table also shows for which patient group the nursing care plan was made. 8 patients had a written plan for "high risk of pressure ulcers". For those patients, interventions aimed at preventing pressure ulcers were performed during the whole time of their hospitalization in the RICU. This amounts to 117 days of interventions in pressure ulcer prevention. It was noted that these patients had a score of 12 points or less, i.e. these patients were assessed as having "high risk" or "very high risk" on the Braden scale. For patients with an 


\begin{tabular}{|c|c|c|c|c|}
\hline $\begin{array}{c}\text { Braden scale } \\
\text { Parameters/points } \\
\text { Assessment at } \\
\text { admission }\end{array}$ & $\begin{array}{l}\text { Number of patients } \\
\text { in relation to the } \\
\text { point score at } \\
\text { admission }\end{array}$ & $\begin{array}{c}\text { Average number of } \\
\text { bed days }\end{array}$ & $\begin{array}{l}\text { Score changes in } \\
\text { relation to the score } \\
\text { at admission }\end{array}$ & $\begin{array}{l}\text { Nursing plan made } \\
\text { during the patient's } \\
\text { stay on the ward }\end{array}$ \\
\hline $\begin{array}{l}\text { Very high risk/ } \\
6-9 \text { points }\end{array}$ & 2 & 9.5 days & $\begin{array}{c}\text { Yes ( } 1 \text { high risk } \\
\text { patient) }\end{array}$ & Yes \\
\hline $\begin{array}{l}\text { High risk/ } \\
\text { 10-12 points }\end{array}$ & 6 & 12 days & $\begin{array}{l}\text { Yes ( } 2 \text { moderate risk } \\
\text { patients; } 1 \text { very high } \\
\text { risk patient) }\end{array}$ & Yes \\
\hline $\begin{array}{l}\text { Moderate risk/ } \\
13-14 \text { points }\end{array}$ & 5 & 8 days & $\begin{array}{c}\text { Yes (3 very high risk } \\
\text { patients; } 1 \text { mild risk } \\
\text { patient) }\end{array}$ & No \\
\hline $\begin{array}{l}\text { Mild risk/ } \\
\text { 15-18 points }\end{array}$ & 7 & 4 days & $\begin{array}{l}\text { Yes ( } 1 \text { high risk } \\
\text { patient; } 1 \text { moderate } \\
\text { risk patient) }\end{array}$ & No \\
\hline $\begin{array}{l}\text { No risk/ } \\
19-23 \text { points }\end{array}$ & 3 & 6 days & No & No plan necessary \\
\hline
\end{tabular}

assessment of "moderate risk" or "mild risk" on the Braden scale at admission, no nursing care plan for "high risk of pressure ulcers" was written.

All patients with a written nursing care plan for "high risk of pressure ulcers" were put on a high protein diet regardless of the way they were fed (orally or through a feeding tube). Patients with no written nursing care plan were not put on a high protein diet.
The nursing care plan for "high risk of pressure ulcers" was written according to the recommendations for standardized plans made by the Croatian Nursing Council.

Table 2 shows the interventions cited in the nursing care plan for the 8 patients that had a written nursing care plan as well as the number of days during which interventions were conducted.

\begin{tabular}{|c|c|c|}
\hline & Interventions & $\begin{array}{l}\text { Total number of days during which } \\
\text { interventions were performed }\end{array}$ \\
\hline 1 & $\begin{array}{c}\text { Change of the patient's position } \\
\text { every } 2 \text { hours }\end{array}$ & 117 days \\
\hline 2 & Assess the risk factors for the development of pressure ulcers & 117 days \\
\hline 3 & Maintain the hygiene of skin and bed linen & 117 days \\
\hline 4 & Ensure optimal hydration of the patient & 117 days \\
\hline 5 & Put pillows under the knees & 117 days \\
\hline 6 & Use Fowler's low position & 64 days \\
\hline 7 & Change the position by raising, not dragging & 117 days \\
\hline 8 & Perform passive extremities exercises & 56 days \\
\hline 9 & Increase the intake of proteins and carbohydrates & 30 days \\
\hline 10 & Use pain medication & 10 days \\
\hline 11 & Control the development of edema & 30 days \\
\hline 12 & Record the current state & 117 days \\
\hline 13 & Educate families about measures to prevent pressure ulcers & 2 days \\
\hline
\end{tabular}


Table 3 shows the average point score for every parameter of the Braden scale. Along with the average point scores for every parameter of the Braden scale, the possible point range as well as the margin point score were shown (3). Consequently, we can note that interventions for patients should be planned in accordance with parameters of sensory perception, activity and mobility as well as friction and shear. The Activity parameter has the lowest point score, while the Moisture parameter has the highest point score. All patients whose Braden scale assessment at admission resulted in very high to high risk were immediately put on a high protein diet, so the Nutrition parameter cannot be correctly assessed. Since interventions were aimed at the Activity, Friction and Shear, Mobility and Sensory Perception parameters, we believe that the harmonization levels between the parameters of the Braden scale are good.

Interventions do not include the usage of pressure ulcer prevention products (mattresses, pillows, etc.), consultation with the physiotherapist (who is involved in patient care in most RICUs), nor do they include the adaptation of interventions to the needs of the individual patient. Planned interventions were carried out during the whole time of the patients' hospitalization. None of the nursing care plans had a written evaluation. For transferred patients, no endevaluations were written and none of the clinical handovers stated whether it was necessary to continue to carry out the nursing care plan.

Two patients developed $1^{\text {st }}$ degree pressure ulcers, which was entered in the pressure ulcer form. At that moment, these patients had an assessment of high risk of pressure ulcer development. No change of plan and interventions was done for those patients.

\section{Discussion}

The month-long study in the RICU showed that the Braden scale was used daily as a pressure ulcer evaluation tool. Based on the Braden scale assessment, interventions are planned and nursing care plans are written. It has been noticed that plans are written only if the assessment on the Braden scale shows a high or very high risk, whereas for Braden scale values that point to a moderate or mild risk no nursing care plans are written. It is difficult to determine why this is so. As part of undergraduate nursing study final papers on the topic of pressure ulcers, the importance of prevention is noted, especially the risk assessment for the development of pressure ulcers, but prevention interventions are usually not linked to the parameters of the Braden or any other scale $(6,7)$. A special emphasis on the nutritional status was noticed, but it was neither linked to the data that existed in the nursing documentation nor with the parameters of the Braden scale that assessed diet (6). Režić and Pauker note their observations where of the 71 patients with pressure ulcers, the Braden scale assessment showed that in 64 cases the Braden scale score was 12 or less, while in 7 cases the score was 14 , showing moderate risk (8).

Since no intervention algorithms for the Braden scale exist, it is possible that nurses lack guidelines on how and when to plan and coordinate pressure ulcer prevention interventions.

All nursing care plans lack evaluation, as well as records about the existing risk of pressure ulcer development in the patient handover.

\begin{tabular}{|cccc|}
\hline & \multicolumn{2}{c}{ Table 3. Braden scale - point score } \\
Braden scale -average points for 20 patients & & \\
Parameters of the Braden scale & $\begin{array}{c}\text { Average points } \\
\text { Sensory perception }\end{array}$ & Possible point range & Margin point score * \\
\hline Moisture & 2.6 & $1-4$ & 3 \\
\hline Activity & 3.1 & $1-4$ & 3 \\
\hline Mobility & 1.1 & $1-4$ & 3 \\
\hline Nutrition & 1.9 & $1-4$ & 3 \\
\hline Friction and shear & 3.0 & $1-4$ & 2 \\
\hline *Margin point scores taken from: Braden Scale Interventions Algorithm (https://www.clwk.ca/buddydrive/file/braden-scale-interventions-algorithm/)
\end{tabular}


Other countries have specially educated wound treatment teams. These teams come to the ward when requested and carry out an assessment of the patients' condition, give recommendations for treatment, continue to follow patients' condition and decide on further measures in case of change in condition. Such teams are needed in our country, too. At the moment, wound treatment teams rarely exist on the institutional level in Croatia. The Commission for Wounds, an example of good practice, shows how it significantly improved the work on the prevention and treatment of pressure ulcers (9).

\section{Conclusion}

The study shows that nurses assess the risk of the development of pressure ulcers daily using the Braden scale for all patients on the ward, but the nursing care plan "High Risk of Pressure Ulcer Development" is written only when the Braden scale assessment shows high/very high risk, whereas no plan is written when the risk is moderate or mild. No evaluations were written for patients who had written plans. The harmonization of the Braden scale assessment with planned interventions showed good harmonization.

The authors feel that it is necessary to develop algorithms for pressure ulcer prevention interventions linked to the parameters of the Braden scale, following the example of other countries. Algorithms give a clear, concise review of interventions that are necessary for pressure ulcer prevention.

\section{References}

1. Narodne novine. Pravilnik o primjeni sestrinske dokumentacije u bolničkim zdravstvenim ustanovama. 2011: 79. Croatian.

2. Guideline: Braden Scale for Predicting Pressure Ulcer Risk in Adults \& Children/Infants. British Columbia Provincial Nursing Skin and Wound Committee. 2014 (cited 2017 Aug 20). Available from: https://www.clwk. ca/buddydrive/file/guideline-braden-risk-assessment/

3. Braden scale Interventions Algorithm. 2014. (cited 2017 Aug 12). Available from: https://www.clwk.ca/ buddydrive/file/braden-scale-interventions-algorithm/

4. Gadd MM, Morris SM. Use of the Braden Scale for pressure ulcer risk assessment in a community hospital setting: the role of total score and individual sub scale in triggering preventive interventions. J Wound Ostomy Continence Nurs. 2014; 41(6): 535-8.

5. Gadd MM. Braden Scale cumulative score versus subscale scores: are we missing opportunities for pressure ulcer prevention? J Wound Ostomy Continence Nurs. 2014; 41(1):86-9.

6. Marković J. Dekubitus kao indikator kvalitete zdravstvene njege [završni rad]. Sveučilište Sjever: Varaždin; 2016. Croatian.

7. Vranar M. Sestrinska skrb za očuvanje integriteta kože bolesnika [završni rad]. Visoka tehnička škola u Bjelovaru: Bjelovar; 2015. Croatian.

8. Režić S, Pauker K. Što nam analiza liste za praćenje dekubitusa može pokazati? Sestrinski glasnik. 2017; 22(1):48-51. Croatian.

9. Pavković Lj, Lacković T. Skrb za pacijente s dekubitusom kao primjer suradnje liječnika i medicinskih sestara. Sestrinski glasnik. 2013; 18(2): 88-94. Croatian. 


\section{USKLADENOST PROCJENE NA BRADEN LJESTVICI S PLANIRANIM INTERVENCIJAMA VEZANIM UZ PREVENCIJU NASTANKA DEKUBITUSA}

\section{Sažetak}

Uvod. Bradenova ljestvica dokazano je pouzdana ljestvica za procjenu rizika za nastanak dekubitusa. Sastavni je dio sestrinske dokumentacije u Republici Hrvatskoj i upotrebljava se u svim bolničkim zdravstvenim ustanovama kao alat kojim procjenjujemo rizik za nastanak dekubitusa. Medicinske sestre koristeći se Bradenovom ljestvicom mogu utvrditi koje intervencije moraju provoditi u svrhu prevencije dekubitusa.

Cilj. Prospektivno praćenje provedeno je na odjelu pulmološke intenzivne skrbi Klinike za plućne bolesti Jordanovac, Zagreb tijekom mjesec dana. Ciljevi su bili: utvrditi usklađenost procjene na Bradenovoj ljestvici s planiranim intervencijama sestrinske dijagnoze visokog rizika za nastanak dekubitusa, utvrditi procjenjuje li se kod svih primljenih pacijenata Bradenova ljestvica, utvrditi procjenjuje li se Bradenova ljestvica svakodnevno za sve pacijente te izrađuju li se planovi zdravstvene njege za pacijente koji imaju rizik za nastanak dekubitusa.

Metode. Izrađen je obrazac u svrhu ovog praćenja u koji su upisivani podaci o spolu, datumu prijema i datumu otpusta te podaci povezani s procjenom po Bradenovoj ljestvici prilikom prijema, tijekom boravka na odjelu te prilikom otpusta.

Rezultati. U praćenom periodu ležalo je 23 pacijenta. Njih 20 imalo je rizik za nastanak dekubitusa, procijenjen po Bradenovoj ljestvici. Za osam pacijenata napisan je plan zdravstvene njege „Visok rizik za nastanak dekubitusa" te su provođene intervencije koje pokazuju dobru usklađenost s parametrima Bradenove ljestvice.

Zaključak. lako je Bradenova ljestvica alat za procjenu rizika za nastanak dekubitusa, praćenje pokazuje mogućnosti veće primjene. To se odnosi na mogućnosti primjene parametara Bradenove ljestvice kao vodiča za odabir intervencija.

Ključne riječi: Bradenova ljestvica, prevencija dekubitusa, plan zdravstvene njege, algoritam intervencija za dekubitus 